Journal of Contemporary Research in Social Sciences

ISSN : 2641-0249

Vol. 3, No. 4, pp. 87-100.

2021

Publisher: Learning Gate

DOI: 10.33094/26410249.2021.34.87.100

(C) 2021 by the authors; licensee Learning Gate

\title{
Impact of Fiscal Prudence and Financial Development on Foreign Direct Investment Inflow: Nigerian Evidence
}

\author{
Mukhtar Shuaibu \\ Department of Social Sciences, Kebbi State Polytechnic, Dakingari, Kebbi State, Nigeria. \\ Email:mukhs001@yahoo.com
}

Received: 19 July 2021; Revised: 23 August 2021; Accepted: 8 September 202 1; Published: 21 September 2021

\begin{abstract}
Foreign direct investment in a globalized and information technology driven environment, as we have today in the 21: century, acted as a driver of growth. This paper provides further evidences on macroeconomic management of FDI in emergent economies especially in Africa. The paper empirically measures the effects of fiscal prudence and financial development on foreign direct investment inflow in Nigeria. It tested the importance of household consumption, domestic credit to the private sector, fixed capital formation, domestic savings, external debt, foreign reserve and financial development for the purpose of ensuring FDI inflow in Nigeria. It findings show that domestic credit to private sector, fixed capital formation, foreign reserve and financial development are statistically significant in the case of Nigeria. The econometric methodologies followed for the study are log-linear regressions and ARDL bound testing. Data was sourced from National Bureau of statistics and World Bank's World Development Index for the period ranging from 1985 to 2018.
\end{abstract}

Keywords: Fiscal prudence, FDI, Household consumption, Fixed capital investment, Domestic credit to private sector, Domestic savings, External debt, Financial development, Foreign reserve, Macroeconomics.

JEL Classification: E21; E22; F3; G15; O16; O19.

\section{Introduction}

The Covid 19 pandemic that ravage the global economy, brought into focus the issue of fiscal sustainability in the face of declining revenue as a result of unprecedented recession in the world economy since the Second World War. Countries everywhere are rushing to find ways to balance their budgets giving the declining revenue; as a result debt level is rising. Learning from what happened in the aftermath of 2008 global financial crisis, FDI inflow is expected to decline post Covid 19 in countries around the world. The two terms in the centre of this, 'fiscal prudence' and 'fiscal profligacy' are often used, interchangeably, to denote whether fiscal policies tend to lead to a sustainable or unsustainable fiscal position (Mauro, Rafael, Ariel, \& Asad, 2013). Meeting government's intertemporal budget constraint is considered important in gauging how much a particular government is able to achieve fiscal prudence. Fiscal prudence deals with how government manages its expected present discounted value of all future fiscal surpluses with the existing stock of public debt. How much does a nation fiscal policy support sustainable economic growth and economic development without causing fiscal crisis? In developing economies of the world, absence of macroeconomic stability indicates failure of government policies, thus, adding to foreign investors' scepticism of the host economy potentialities (Boateng, Hua, Nisar, \& Wu, 2015). According to Rădulescu and Druica (2014), economic literature has shown that fiscal incentives, spending for infrastructure and the depreciation of national currency are important factors in attracting FDI, but they (alone) cannot compensate for lack of other important factors needed for the creation of conducive atmosphere for hosting FDI. Research works by Wint and Williams (2002); Garibaldi, Mora, Sahay, and Zettelmeyer (2002) and Suchismita and Sudipta (2012) show that a 
stable economy attracts more FDIs. Different types of indicators, such as fiscal balance, government debt to GDP, government debt to revenues, and government expenditure to GDP are taken as proxies for fiscal health of a country's economy; others include foreign reserve, ratio of national savings to GDP, and aggregate external debt. Abdoul (2012) found that larger countries attracted more FDI than smaller ones. However, regardless of size, more open and politically stable countries offering higher returns attracted FDI. Okpara (2012) found that natural resource, fiscal incentives, favorable government policies, exchange rate, and infrastructural development had positive effect on FDI inflows in Nigeria.

Over the years, foreign direct investment (FDI) has been recognized as an important catalyst for growth and development of developing countries. Advantageously, FDI comes with it foreign technology, highly needed managerial skills, marketing acumen and knowledge sharing. But, factors such as inferior technology, lack of skill manpower, poor economic policy, corruption and political uncertainties have been widely associated with reduction in the amount of FDI going to poor countries. This is despite economic theory suggesting that capital shall go to where demand for it is higher. The increase in FDI around the world in the last five decades is a testimony to the increase in globalisation and movement of capital. It is estimated that FDI has increased 14 times in the last three decades while global GDP only increased three times during the same time (McEwan, 2001; Taguchi \& Pham, 2019). For example, in the history of colonial Britain, funds coming from abroad (much of it spoils of the empire) have played important role in the Great Britain early industrialization (McEwan, 2001). Economic downturns such as recession and financial crisis cause banking failure and reductions in savings and investment; because of these investments from the outsides of a country such as FDI are highly welcomed in the developing nations of the world. Debelle and Preston (1995), have provided evidences of the importance of cash flow in determining investment. The level of financial development and industrial development may have played a role in attracting FDI into a region of a country (Agyapong \& Bedjabeng, 2019), for example, almost 87\% of FDI into Nigeria in 2019 went to Lagos state which acts as financial and industrial hub of Nigeria. In the past, various Nigerian governments had made various efforts to attract FDI including the establishment of industrial development coordinating committee (IDCC) in 1988. In 1981, federal government created an office in the ministry of industry to coordinate and expedite the processing of foreign companies applications (Aremu, 1991). There were also the structural adjustment program (SAP) and the Nigerian Investment Promotion Commission (NIPC). Recently, Nigerian government has relied so much on Nigerians living in the diaspora for the attraction of the necessary FDI into the country. Hence, the recent establishment of the Nigerians in Diaspora Commission (NIDCOM) to coordinate matters related to the diaspora. According to recent estimates, Nigerians in the diaspora contributed about $\$ 23.63$ billion to the Nigerian GDP in 2018, amounting to about $6.1 \%$ of GDP (PWC, 2019).

Despite the importance of FDI, in the long run there is no alternative to domestic saving because inadequate domestic savings will eventually pull down investment rates, either directly or through constraints on the continued build-up of foreign liabilities, which must be repaid by using domestic savings (The World Bank, 1993). Foreign direct investment is likely to be harmful to the growth and welfare of a developing country when investors are sheltered from competition in the domestic market and burdened with high domestic content, mandatory joint venture and technology-sharing requirements (Moran, 1999). Countries such as Japan, South Korea and Taiwan have regulated FDI flow into their countries during the early stages of their industrialization process (McEwan, 2001); these nations did not depend on FDI to achieve industrialization. Countries that regulated FDI such as those mentioned above, succeeded better than those who did not regulate FDI such as Brazil, Colombia and Mexico during their early stages of industrialization (McEwan, 2001). In Australia, Debelle and Preston (1995) found little evidence with regards to the effects of foreign influences on domestic investment, although an indirect channel operating through business confidence was identified. Despite these, this paper tries to determine the dynamism and effects of selected macroeconomic variables on inflow of FDI into Nigerian economy. The econometric methods of analysis followed to determine the veracity of the 
proposed model are log-linear linearization of multiple regressions equation and ARDL bound testing approach. The use of log linear approach ensured that problems encountered with nonlinear equations are overcome and the problems of heteroskedasticity and autocorrelation are corrected. ARDL is noted for its ability to provide both short run and long run equilibriums in a single equation model. ARDL model applies a general-to-specific modeling framework by taking a sufficient number of lags to capture the data-generating process.

\section{Literature Review and Theoretical Framework}

Investment is the accumulation of real capital goods over a period of time by enterprises and firms with the purpose of yielding future flow of goods and services. FDI is defined as a form of international inter-firm co-operation involving significant equity stake and effective management decision power in, or ownership control of, foreign enterprises (De Mello, 1999). But, according to Thirlwall (1994), FDI refers to investment by multinational companies with headquarters in developed countries. This investment involves not only a transfer of funds including the reinvestment of profits, but also a whole package of physical capital, techniques of production, managerial and marketing expertise, products, advertising and business practices for the maximization of global profits. In economics parlance, investment is categorized as component of aggregate demand just like consumption. Hence, the names investment demand and consumption demand. Investment responds to changes in aggregate demand. Consumption influence the level of investment in any economy, whether domestic or foreign investment. Nigeria, unlike many other countries, has a big domestic market with population of over 200 million people; this alone might have acted as one of the major attracters of FDI into Nigeria; just like it was the case with India and China. Thus, the level of domestic consumption shall be expected to have positive relationship with FDI (Shah, 2016; Yimer, 2017). The issues of linkages and interconnectivity among world economies have been tackled by scholars in many different ways both in theoretical contributions and academic gatherings. A number of such works look at the matter from the perspective of trading in goods; others viewed it from movement of capital and financial resources between nations. For example, Abdullahi (2017); Abdullahi. (2019) observed that developed countries stock markets tend to correlate with their developed countries counterparts and that volatility in one equity market affects the volatility in other connected markets around the world. Shuaibu (2016) found that in general trade liberalisation has mixed effects on macroeconomic performance.

According to Feldstein and Horioka (1980), existence of low correlation between savings and investment indicates capital mobility while higher correlation between them suggests capital immobility. Both saving and investment provide higher standard of living at a later date. Between the years of 1960 to 1990, high performing Asian economies were the only set of developing countries where savings exceed investment, making them exporters of capital (The World Bank, 1993). In the literature on international trade and finance, saving minus investment is equal to net export. When saving is greater than investment you export and when investment is greater than saving you import. The difference between saving and investment is therefore referred to as net capital outflow. In this context, where free movement of goods and services is seamless, a nation can spend more than it produces by borrowing from abroad, it can spend less than it produces and lend the difference to foreigners (Mankiw, 2007). Unlike in closed economy, in an open economy investment can be financed by borrowing from abroad or through FDI or portfolio investment. Exchange rate in the receiving country of FDI plays an important role in determining the flow of FDI into that country economy; hence, the need for foreign exchange stability and the larger macroeconomic stability. Macroeconomic stability plays an important role in ensuring effective use of FDI and without it FDI may not come and when it comes, the FDI tends to be low in volume. International interest rate plays an important role in influencing the movement of investments around the world. And, according to Mankiw (2007), of the three types of investment (i.e. business fixed investment, residential investment and inventory investment), business fixed investment account for about three quarters of the total. As noted in the case 
of East Asian economies, accumulation of productive assets is the foundation of economic growth (The World Bank, 1993).

Agyapong and Bedjabeng (2019) examine the role of external debt and foreign direct investment in influencing financial development in Africa. Their findings showed that external debt and foreign direct investment have positive relationship with financial development in African economies. Their paper measures the dual effects of external debt and FDI on financial development, viewing both of them as external sources of financing development. The authors used domestic credit to private sector as proxy for financial development. Takyi and Obeng (2013) studied the determinants of financial development in Ghana using ARDL model for data ranging from 1988 to 2010. Their result shows that there is a cointegrating relationship between FDI and financial development. Shah (2016), tried to gauge the importance of prudent macro-economic management in the decision of foreign direct investors, using annual data from 1990 to 2015. The results show that better infrastructure, trade and investment liberalisation have significant effects on FDI inflows in Africa. He also found that prudent management of macro-economy and healthy business policies manifested through stable macroeconomic indicators increased the ability of African countries to receive additional Foreign Direct Investment. Rădulescu and Druica (2014), measure the impact of fiscal policy on foreign direct investments in Romania which is an emerging economy. The result show that fiscal factors (mainly direct taxes) played less important role in the short term. They suggested that Romania shall focus on improving factors such as infrastructure, legal and political stability. As they observed, 'only then can the fiscal stimulus be effective in attracting FDIs and supporting the economic growth in the same time'. Suchismita and Sudipta (2012) studied FDI inflow in the light of the global recession of 2008/9. They tried to determine the FDI's encouraging or debilitating effect of government balances relative to other determinants of inward FDI. Fiscal health is found to be a very significant determinant of FDI inflows, underlining the significance of pruning government deficits for sustainable FDI in the post-crisis scenario. Yimer (2017), noted that macroeconomic instability negatively affect FDI inflows in Ethiopia. In addition, better political stability, government effectiveness and regulatory quality, and better performance of the rule of law are found to positively affect FDI inflows to the country. Anyanwu (2012) found domestic financial development to have a negative effect on FDI inflows.

Geda and Yimer (2015) estimated FDI determination for Africa. Using a panel co-integration approach over 1996-2012 they found market size, availability of natural resources, openness to international trade, a stable macroeconomic environment, better infrastructure, and an effective bureaucracy as having strong positive impact on FDI. Katircioglu and Naraliyeva (2006) investigated long run equilibrium relationship and direction of causality between economic growth, domestic savings and foreign direct investment in Kazakhstan; the co-integration results suggest a long-run equilibrium relationship between each pair of the variables except between Savings and FDI. Granger causality results suggest unidirectional causations running from both Savings and FDI to economic growth. Taguchi and Pham (2019) examines the effect of FDI on economic growth and domestic investment with a focus on Vietnamese provinces by conducting the Granger causality and impulse response tests under a vector auto-regression (VAR) estimation using panel data. The results show that that FDI causes economic growth in the FDI-intensive region, whereas economic growth induces FDI in the FDI-less-intensive region. De Mello (1999) estimates the impact of foreign direct investment (FDI) on capital accumulation, and output and total factor productivity (TFP) growth in a recipient country economy. Time series and panel data evidence were used for OECD and non-OECD countries. The results show that the extent to which FDI is growth-enhancing depends on the degree of complementarity and substitution between FDI and domestic investment. Buckley et al. (2007), investigated the determinants of Chinese outward direct investment (ODI). They tested hypotheses using official Chinese ODI data collected between 1984 and 2001. The results showed Chinese ODI to be associated with high levels of political risk, cultural proximity to host countries, host market size, geographic proximity and host natural resources endowments. Asiedu (2001), explore factors that affected FDI in Sub Saharan Africa, the result indicated that openness to trade promoted FDI, but 
return on investment and better infrastructure have no significant impact. Adekunle (2020); Adebayo and Gambiyo (2020); Cookey and Eniekezimene (2020) also found that openness to trade helps FDI inflows. In a related work on effects of FDI on economic growth in developing countries (Dinh, Vo, \& Nguyen, 2019) noted that FDI helps stimulate economic growth in the long run, although it has a negative impact in the short run.

Mishra and Jena (2019), examined the determinants of foreign direct investment (FDI) from six developed countries (USA, Japan, Germany, Netherlands, UK and France) into four Asian economies (China, Korea, India and Singapore). The results revealed factors such as market size of host and source country, distance, common language and common border influence FDI. Others are inflation rate, real interest rate, institutional and infrastructural factors such as telecommunication, degree of openness, index of globalisation and index of economic freedom. Nasiru and Usman (2013) explore the relationship between savings and investment in Nigeria during the period 1980-2011. The results of the ARDL Bounds test show long run relationship between savings and investment. The results further support the Feldstein and Horioka (1980) hypothesis that postulates low capital mobility internationally. But, in a study on capital mobility in West Africa using panel data by Hassan (2016), the study found low association between domestic savings and domestic investment and hence higher capital mobility in West Africa. The paper confirmed that the Feldstein-Horioka puzzle did not hold for West Africa. In a study on FDI determinants in Nigeria, Salako and Adebusuyi (2001) found positive relationship between government capital investment and FDI. The study also found credit to private sector also showed positive relationship to FDI. Hermes and Lensink (2003) empirically investigated the role development of the financial system plays in enhancing positive relationship between FDI and economic growth in the receiving country. The empirical investigation strongly suggests that the development of financial system of the recipient country is influential precondition for FDI to have a positive impact on economic growth. High external debt ratio in developing countries was associated with reduction in investment (Front \& Krugman, 1990) and a study on Nigeria also found the same result (Salako \& Adebusuyi, 2001). In a similar study by Ekpo (1997), the author examined the relationship between foreign direct investment (FDI) in Nigeria and some macroeconomic variables. The empirical results suggested that high debt service and low credit ratings discourage FDI; the results also show that FDI is sensitive to real per capita income and low rates of inflation.

\section{Data and Methodology}

\subsection{Data}

As already reviewed, there exists a large body of literature on the determinants of FDI inflows. While most of them are cross-country studies in the developing world in general and Sub Saharan Africa in particular, little has been done to investigate the determinants of FDI flows to Nigeria with respect to fiscal prudence. While cross-country studies are generally seen as able to identify the factors that drive FDI and examine its impact across countries, they usually fail to provide in-depth analyses and country specific factors that are crucial in attracting FDI. This paper measures how macroeconomic variables such as household consumption (HC), fixed capital formation (FCF), domestic credit to the private sector (DCP), domestic savings (DS), external debt (ED), financial development (FD) and foreign reserve (FR) affect foreign direct investment (FDI) in Nigeria. The variables external debt, foreign reserve and domestic savings measure the economy wide fiscal prudence level; while the variables financial development and domestic credit to private sector measure financial development; the remaining two variables household consumption and fixed capital formation are control variables. In order to avoid the problems of multicollinearity, aggregate consumption was not used for the study because it is the aggregation of household consumption, public consumption, private consumption and investment consumption spending. The data was generated from National Bureau of Statistics (NBS) and World Bank for the period ranging from 1985 to 2018. The softwares used for the analysis are STATA 15 and Eview 9. The methodology followed in the analysis is in line with the long standing 
econometric tradition and the mainstream empirical analysis. It was also used by a number of previous works measuring the performance of FDI around the world.

\subsection{Descriptive Statistics}

The means, variance and correlation of the macroeconomic variables are shown in the Table 1 and 2. The cross correlations show positive correlation between FDI and HC, FCF, DCP, FD and FR; but negative correlations with DS and ED.

Table-1.

Summary statistics.

\begin{tabular}{c|c|c|c|c|c|c|c|c}
\hline & FD & HC & FCF & DCP & DS & ED & FDI & FR \\
\hline Mean & 0.203939 & $1.34 \mathrm{E}+11$ & $4.42 \mathrm{E}+10$ & 10.03588 & 38.62353 & 27569159 & 3109.898 & 19616501 \\
\hline Median & 0.200000 & $6.52 \mathrm{E}+10$ & $3.41 \mathrm{E}+10$ & 8.240000 & 38.07000 & 29448801 & 2083.635 & 8940349. \\
\hline Maximum & 0.290000 & $4.15 \mathrm{E}+11$ & $9.75 \mathrm{E}+10$ & 22.29000 & 68.98000 & 47047232 & 8914.890 & 53599284 \\
\hline Minimum & 0.150000 & $1.68 \mathrm{E}+10$ & $1.88 \mathrm{E}+10$ & 4.960000 & 13.42000 & 9617378. & 193.2200 & 932989.8 \\
\hline Std. Dev. & 0.032877 & $1.32 \mathrm{E}+11$ & $2.19 \mathrm{E}+10$ & 4.377985 & 15.59999 & 8602629. & 2532.592 & 18719298 \\
\hline Skewness & 0.619964 & 0.867109 & 0.558958 & 1.142947 & -0.003846 & -0.255122 & 0.956494 & 0.499620 \\
\hline Kurtosis & 2.963197 & 2.248447 & 2.208890 & 3.672457 & 2.000489 & 2.728827 & 2.734922 & 1.596795 \\
\hline Jarque-Bera & 2.115814 & 5.060816 & 2.657090 & 8.043134 & 1.415365 & 0.473000 & 5.283866 & 4.203909 \\
\hline Probability & 0.347182 & 0.079627 & 0.264862 & 0.017925 & 0.492785 & 0.789386 & 0.071223 & 0.122217 \\
\hline Sum & 6.730000 & $4.55 \mathrm{E}+12$ & $1.50 \mathrm{E}+12$ & 341.2200 & 1313.200 & $9.37 \mathrm{E}+08$ & 105736.5 & $6.67 \mathrm{E}+08$ \\
\hline Sum Sq. Dev. & 0.034588 & $5.71 \mathrm{E}+23$ & $1.58 \mathrm{E}+22$ & 632.5028 & 8030.870 & $2.44 \mathrm{E}+15$ & $2.12 \mathrm{E}+08$ & $1.16 \mathrm{E}+16$ \\
\hline Observations & 33 & 34 & 34 & 34 & 34 & 34 & 34 & 34 \\
\hline
\end{tabular}

Table-2.

Level of correlation between the variables.

\begin{tabular}{|c|c|c|c|c|c|c|c|c|}
\hline \multicolumn{2}{|c|}{ Correlation } & \multirow[b]{2}{*}{$\mathrm{HC}$} & \multirow[b]{2}{*}{$\mathrm{FCF}$} & \multirow[b]{2}{*}{ DCP } & \multirow[b]{2}{*}{ DS } & \multirow[b]{2}{*}{ ED } & \multirow[b]{2}{*}{ FDI } & \multirow[b]{2}{*}{ FR } \\
\hline Probability & FD & & & & & & & \\
\hline \multirow[t]{2}{*}{ FD } & 1.000000 & & & & & & & \\
\hline & ----- & & & & & & & \\
\hline \multirow[t]{2}{*}{$\mathrm{HC}$} & 0.715191 & 1.000000 & & & & & & \\
\hline & 0.0000 & ----- & & & & & & \\
\hline \multirow[t]{2}{*}{$\mathrm{FCF}$} & 0.721736 & 0.787572 & 1.000000 & & & & & \\
\hline & 0.0000 & 0.0000 & ----- & & & & & \\
\hline \multirow[t]{2}{*}{ DCP } & 0.824831 & 0.739453 & 0.569453 & 1.000000 & & & & \\
\hline & 0.0000 & 0.0000 & 0.0005 & ----- & & & & \\
\hline \multirow[t]{2}{*}{$\mathrm{DS}$} & -0.720635 & -0.849643 & -0.541990 & -0.788582 & 1.000000 & & & \\
\hline & 0.0000 & 0.0000 & 0.0011 & 0.0000 & ---- & & & \\
\hline \multirow[t]{2}{*}{ ED } & -0.576435 & -0.356314 & -0.620572 & -0.485939 & 0.238811 & 1.000000 & & \\
\hline & 0.0004 & 0.0418 & 0.0001 & 0.0041 & 0.1808 & ----- & & \\
\hline \multirow[t]{2}{*}{ FDI } & 0.692579 & 0.684311 & 0.558342 & 0.815244 & -0.673122 & -0.662806 & 1.000000 & \\
\hline & 0.0000 & 0.0000 & 0.0007 & 0.0000 & 0.0000 & 0.0000 & ----- & \\
\hline \multirow[t]{2}{*}{$\mathrm{FR}$} & 0.841777 & 0.795565 & 0.665051 & 0.829666 & -0.753183 & -0.628144 & 0.901790 & 1.000000 \\
\hline & 0.0000 & 0.0000 & 0.0000 & 0.0000 & 0.0000 & 0.0001 & 0.0000 & ----- \\
\hline
\end{tabular}

\subsection{Model}

The strength of the model is in its simplicity and practicality, giving it advantage over mathematically complex models with less practical applications. The model is more useful for looking at the real conditions of FDI in a country. The variables used for the study were derived from economic 
theory and previous empirical works. But, the set of variables used for the work differs from those used in many of the previous works in this area; this is done in order to isolate the effect of the selected variables on FDI. The variables external debt, external reserve and domestic savings were used to measure fiscal prudence while domestic credit to private sector and financial development variables were used to measure financial development.

$$
F D I=\beta_{1}+\beta_{2} H C+\beta_{3} F C F+\beta_{4} D C P+\beta_{5} D S+\beta_{6} E D+\beta_{7} F D+\beta_{8} F R+\mu
$$

Where;

FDI $=$ Foreign Direct Investment;

$\mathrm{HC}=$ Household consumption;

$\mathrm{FCF}=$ Fixed Capital Formation;

$\mathrm{DCP}=$ Domestic Credit to Private Sector;

DS = Domestic Savings;

$\mathrm{ED}=$ External Debt;

$\mathrm{FD}=$ Financial Development;

$\mathrm{FR}=$ Foreign Reserve;

$\beta=$ Parameters;

$\mu=$ Error term.

\subsection{Log Linear Regression analysis}

The problems of nonlinearity make it compulsory for econometricians to be cautious when building empirical models. Nonlinearity is expected in most economic relationship given the complexity of the real world. Nonlinear model can be estimated with OLS after the necessary transformation by means of $\log$ linear transformation (Koutsoyiannis, 1977). The data for the study are transformed into natural logarithms due to expectation of nonlinearities in the relationships on the basis of theory and previous empirical work such as Buckley et al. (2007). Thus, the logarithm form of our model is

$$
\begin{gathered}
\ln F D I=\beta_{1}+\beta_{2} \ln H C+\beta_{3} \ln F C F+\beta_{4} \ln D C P+\beta_{5} \ln D S+\beta_{6} \ln E D+\beta_{7} \ln F D+ \\
\beta_{8} \ln F R+\mu
\end{gathered}
$$

\subsection{Auto-Regressive Distributive Lag (ARDL) Approach to Co-Integration}

ARDL approach was developed by Pesaran, Shin, and Smith (1996); Pesaran, Shin, and Smith (2001) and Pesaran and Shin (1999). ARDL method can distinguish between dependent and explanatory variables and remove the problems that may arise due to the presence of auto-correlation and endogeneity. ARDL method estimates both the short-run and long-run relationships simultaneously and provides unbiased and efficient estimates. In addition, ARDL model permits co-integration relationship to be estimated by OLS once the lag order of the model is identified. To examine the longrun relationship and the dynamic interaction between the dependent variable (FDI) and the independent variables, our ARDL model is as follows:

(3)

$$
\begin{aligned}
\Delta l n F D I=\beta_{1}+ & \beta_{2} \ln F D I_{t-1}+\beta_{3} \ln H C_{t-1}+\beta_{4} l n F C F_{t-1}+\beta_{5} \ln D C P_{t-1}+\beta_{6} \ln D S_{t-1}+ \\
& \beta_{7} \ln E D_{t-1}+\beta_{8} \ln F D_{t-1}+\beta_{9} \ln F R_{t-1}+\sum_{i=0}^{p} \delta_{1} \Delta l n F D I_{t-1}+ \\
& \sum_{i=0}^{p} \delta_{2} \Delta H C_{t-1}+\sum_{i=0}^{p} \delta_{3} \Delta l n F C F_{t-1}+\sum_{i=0}^{p} \delta_{4} \Delta \ln D C F_{t-1}+ \\
& \sum_{i=0}^{p} \delta_{5} \Delta l n D S_{t-1}+\sum_{i=0}^{p} \delta_{6} \Delta \ln E D_{t-1}+\sum_{i=0}^{p} \delta_{7} \Delta \ln F D_{t-1}+ \\
& \sum_{i=0}^{p} \delta_{8} \Delta l n F R_{t-1}+\mu
\end{aligned}
$$

The joint hypotheses to be tested for bound testing are as follows:

$H_{0}: \beta_{2}=\beta_{3}=\beta_{4}=\beta_{5}=\beta_{6}=\beta_{7}=\beta_{8}=\beta_{9}=0$ 


$$
H_{1}: \beta_{2} \neq 0, i=1,2, . ., 9
$$

If our F-statistic is higher than the upper bound critical value, the null hypothesis is rejected, indicating there is a long-run relationship between the lagged level variables in the model. But, if the Fstatistic falls below the lower bound, then the null hypothesis cannot be rejected and no long-run relationship exists. However, if the F-statistic falls between the upper and the lower bound critical values, the inference is considered inconclusive. At this condition, the order of integration of each variable should be determined before any inference can be made.

\section{Results and Discussion}

The Result of the ARDL bound testing show that the F-statistics value is greater than the upper bound critical value; thus, we reject the null hypothesis and accept the alternative hypothesis that says there is presence of long run cointegration relationship (see Table 3). The results of the ARDL long run econometric tests conducted show that the following variables are statistically significant: domestic credit to the private sector, fixed capital formation, financial development and foreign reserve (see appendix section for details of the results of the various tests). But, the following variables are statistically insignificant, though they have the correct signs: household consumption, external debt and domestic savings. The results from the log linear regression show that financial development and foreign reserve are statistically significant. Thus, FD and FR are statistically significant in the models, but the sign of FR in the case of ARDL long run testing is negative while in the case of the log linear model is positive which may be connected with the result being that of short run while the ARDL's long run. ARDL model is considered more efficient and robust. The results may have confirmed the importance of fiscal prudence as represented by foreign reserve and financial development as represented by domestic credit to private sector for the attraction of FDI.

Table-3.

ARDL bound test.

Null Hypothesis: No long-run relationships exist

\begin{tabular}{l|c|c}
\hline Test Statistic & Value & \multicolumn{2}{l}{ K } \\
\hline F-statistic & 12.86530 & 7 \\
\hline Critical Value Bounds & I1 Bound \\
\hline Significance & Io Bound & 2.89 \\
\hline $10 \%$ & 1.92 & 3.21 \\
\hline $5 \%$ & 2.17 & 3.51 \\
\hline $2.5 \%$ & 2.43 & 3.9 \\
\hline $1 \%$ & 2.73 &
\end{tabular}

Table-4.

Comparison of the coefficients of the tests results.

\begin{tabular}{c|c|c|c}
\hline & Variable & ARDL & Log linear \\
\hline 1 & HC & -0.138529 & 13.61044 \\
\hline 2 & FCF & 1.190894 & 0.573200 \\
\hline 3 & DCP & 4.691670 & -0.858952 \\
\hline 4 & DS & 0.236956 & 0.720905 \\
\hline 5 & ED & -0.180454 & 0.163162 \\
\hline 6 & FD & -5.300363 & -0.742566 \\
\hline 7 & FR & -0.490250 & -2.776463 \\
\hline
\end{tabular}

The positive sign of domestic credit to the private sector means that FDI response positively to changes in domestic credits to the private sector, implying that the availability of credit encourage investor to enter the Nigeria market with the hope of finding local sources of capital extension. This 
finding is in line with the work of Agyapong and Bedjabeng (2019) who also found that FDI is positively related with financial development proxy by domestic credit to the private sector. Nigerian banking industry is one of the most capitalized in Africa with some of them having branches across Africa and beyond. The Nigerian bond market is also maturing with Nigerian government increasingly relying on it for its finances. At the same time, the volume of FDI coming to Nigeria has been on the increased. The negative but statistically insignificant relationship between FDI and external debt may indicate that increase in debt burden discourage foreign investors from investing in Nigeria. This is also associated with unfavorable credit rating and high debt service cost which are some of the barometers investors use before committing their resources in any country. Previous study by Ekpo (1997) show similar signs between FDI and debt service cost in Nigeria. This is also true with other countries around the world that were declared bankrupt and unable to finance their budgets. External debt is a component of financial risk (Nonnenberg \& Mendonca, 2004). Highly indebted countries have high transfer risks- the risk of potential restrictions on the ability to transfer funds across national boundaries. Higher transfer risks cause foreign capital to move out of a country and new FDI flows to be re-routed to safer locations (Yimer, 2017). But because of the statistical insignificant result of the external debt in the analysis, more data may be needed to confirm the actual value of the variable.

Fixed capital formation is shown to have positive and statistically significant result. This means that infrastructures spur FDI in Nigeria. This result is consistent with the previous result reviewed in the literature such as Shah (2016) and that of Geda and Yimer (2015). While correlation analysis show positive relation between FDI and financial development, the other econometric tests show negative relations and statistically significant. The positive relationship was what was expected a priori, because financial development shall be expected to spur FDI. But, the negative relationship may be interpreted as the absence of financial deepening and concentration of financial institutions in one section of the country (Lagos), while the vast majority of the population lacks access to the system. Thus, the quality of financial development is what matters not the quantity. Also higher financial development may suggest lower need for external finances such as FDI, since the domestic market is matured enough to cater for that. Our result of negative relation between FD and FDI is also consistent with the findings of Anyanwu (2012).

The positive sign of the foreign reserve variable was expected a priori because large foreign reserve is an indication of credit worthiness and financial viability of a nation. Foreign reserve is also an indication of the level of wealth of a nation; some of the wealthiest nations in the world are the biggest destinations of FDI in the world.

Around the world, nations use foreign reserves to keep a fixed rate value, maintain (competitively priced) exports, remain liquid in case of economic and financial crisis, and provide confidence to the outside investors. In addition, countries need foreign reserves to pay external debts, afford the needed capital to fund the various sectors of their economies, as well as profit from diversified portfolios made possible by maintenance of the reserve.

Thus, the positive relationship here shall not be surprising. But as shown by the long run ARDL result, in the long run foreign reserve may be negatively related with FDI. Household consumption and domestic savings are statistically insignificant and with negative and positive signs, respectively. Previous empirical works such as that of Katircioglu and Naraliyeva (2006) also found absence of cointegration between saving and FDI in Kazakhstan. Salako and Adebusuyi (2001) also found positive relationship between credit to private sector and FDI; further supporting our findings of positive relationship between FDI and credit to the private sector. The study also supports our finding of negative relationship between FDI and external debt. Overall, our econometric models are good for the analysis looking at the high R, R square and F statistics. The method of analysis deploy here have fitted the data as shown by the results statistics in the appendix section. As earlier observed; the models deal with the problems of heteroskedasticity and autocorrelation. 


\section{Conclusion and Policy Implications}

Foreign direct investment in a globalized and information technology driven environment, as we have today in the $21^{\text {st }}$ century, has acted as a driver of growth as shown by previous econometric works and from the analyses in this paper. FDI is viewed by economists and policy makers as one of the key macroeconomic variables that government in the developing countries of the world cannot keep their eyes off. The way countries at various stages of development struggle to attract FDI are testimonies to this. The heighten competition for FDI make it mandatory for countries especially those in developing world to rethink their strategy and laydown the required ground for attracting the highly needed investment. The results from this paper show the importance of the provision of domestically sourced credit to the private sector of the Nigerian economy. Nigerian government shall do all in its power to ensure the reduction of cost of borrowing through ensuring lower interest rate charges and low inflation rate. The federal government shall avoid policies that result in crowding out private sector borrowers and ensure (through the Central bank of Nigeria) provision of long term development capital to the industrial sector of the economy. Government shall also reduce its external debt burden as doing so will send the right signal to investors around the world. Since external debt is found to have negative relationship with FDI, Nigerian government shall explore internal sources of borrowing that do not contradict it overall economic objectives. Nigerian government shall reduce the existing level of external loan and avoid programs that are tied with increasing its external debt burden. Government shall increase the level of financial deepening in the economy by increasing the reach of the Nigerian financial institutions and boosting the number of Nigerians with formal bank account. Quality shall be given priority over quantity in the development of the financial sector. Nigeria shall borrow a leaf from countries such as Malaysia and South Korea when it comes to financial development, as these countries have done excellently well in this regard, prioritizing quality over quantity. The results of this study also show the importance of building foreign reserve as a positive and effective signal for attracting FDI. Nigerian government shall pursued policies that make it possible to build its foreign currency reserve. At the end, all that this study tells us is that there is no alternative to achieving macroeconomic stability and fiscal prudence. Nigeria and other developing countries of the world shall go for it. It is a price worth sacrificing for.

\section{References}

Abdoul, G. (2012). What drives foreign direct investments in Africa? An empirical investigation with panel data. Accra: African Center for Economic Transformation (ACET).

Abdullahi, S. I. (2017). Stock market linkage, financial contagion and assets price movements: Evidence from Nigerian stock exchange. Journal of Advanced Studies in Finance (JASF), 8(16), 146-159.

Abdullahi., S. I. (2019). Measuring volatility linkage, clustering and sensitivity to external shocks in Nigerian stock index. International Journal of Financial Services Management, 9(4), 345-368. Available at: https://doi.org/10.1504/ijfsm.2019.10024218.

Adebayo, E. O., \& Gambiyo, S. P. (2020). Economic analysis of the determinants of foreign direct investment (FDI) in Nigeria. Arch Bus Res, 8(1), 74-81. Available at: https://doi.org/10.14738/abr.81.7542.

Adekunle, O. E. (2020). The short and long run determinants of foreign direct investment in Nigeria. Management $\underbrace{2}$ Economics Research Journal, 2(4), 45-65. Available at: https://doi.org/10.48100/merj.v2i4.124.

Agyapong, D., \& Bedjabeng, K. A. (2019). External debt stock, foreign direct investment and financial development: Evidence from African economies. Journal of Asian Business and Economic Studies, 27(1), 81-98. Available at: https://doi.org/10.1108/jabes-11-2018-0087.

Anyanwu, J. C. (2012). Why does foreign direct investment go where it goes?: New evidence from African countries. Annals of Economics and Finance, 13(2), 425-462.

Aremu, J. (1991). Industrial development coordinating committee (IDCC) and foreign private investment (FDI) in Nigeria. Economic and Financial Review, 29(4), 327-340

Asiedu, E. (2001). On the determinants of foreign direct investment to developing countries: Is Africa different? World Development, 30(1), 107-1 19. Available at: https://doi.org/10.1016/s0305-750x(01)00100-0.

Boateng, A., Hua, X., Nisar, S., \& Wu, J. (2015). Examining the determinants of inward FDI: Evidence from Norway. Economic Modelling, 47, 118-127. Available at: https://doi.org/10.1016/j.econmod.2015.02.018.

Buckley, P. J., Clegg, L. J., Cross, A. R., Liu, X., Voss, H., \& Zheng, P. (2007). The determinants of Chinese outward foreign direct investment. Journal of International Business Studies, 38(4), 499-518. 
Cookey, I. F., \& Eniekezimene, F. A. (2020). Studying determinants of foreign direct investment in Nigeria: An empirical investigation. Asian Journal of Economics, Business and Accounting, 17(2), 73-84. Available at: https://doi.org/10.9734/ajeba/2020/v17i230258.

De Mello, L. R. (1999). Foreign direct investment-led growth: Evidence from time series and panel data. Oxford Economic Papers, 51(1), 133-151. Available at: https://doi.org/10.1093/oep/51.1.133.

Debelle, G., \& Preston, B. (1995). Consumption, investment and international linkages. Reserve Bank of Australia, Research Discussion Paper No. 9512.

Dinh, T. T.-H., Vo, D. H., \& Nguyen, T. C. (2019). Foreign direct investment and economic growth in the short run and long run: Empirical evidence from developing countries. Journal of Risk and Financial Management, 12(4), 1-11. Available at: https://doi.org/10.3390/jrfm12040176.

Ekpo, A. H. (1997). Foreign direct investment in Nigeria: Evidence from time series data. CBN Economic E Financial Review, $35(1), 59-78$.

Feldstein, M., \& Horioka, C. (1980). Domestic saving and international capital flow. Economic Journal, 90(358), $314-329$. Available at: https://doi.org/10.2307/2231790.

Front, K., \& Krugman, P. (1990). Market based debt reduction for developing countries: Principles and prospects. Cambridge Massachusetts: NBER.

Garibaldi, P., Mora, N., Sahay, R., \& Zettelmeyer, J. (2002). What moves capital to transition economies. IMF Working Paper, No. 0264.

Geda, A., \& Yimer, A. (2015). Determinants of foreign direct investment inflows to Africa: A panel co-integration evidence using new analytical country classification. AAU Dep Economics Working Paper No. 4. Addis Ababa University.

Hassan, I. B. (2016). International capital mobility in West Africa: A panel cointegration approach. Cogent Economics \& Finance, 4(1), 1256023. Available at: https://doi.org/10.1080/23322039.2016.1256023.

Hermes, N., \& Lensink, R. (2003). Foreign direct investment, financial development and economic growth. Journal of Development Studies, 40(1), 142-163.

Katircioglu, S. T., \& Naraliyeva, A. (2006). Foreign direct investment, domestic savings and economic growth in Kazakhstan: Evidence from co-integration and causality tests. Investment Management and Financial Innovations, 3(2), 34-45.

Koutsoyiannis, A. (1977). Theory of econometrics. London: MacMillan.

Mankiw, N. G. (2007). Macroeconomics. New York: Worth Publishers.

Mauro, P., Rafael, R., Ariel, B., \& Asad, Z. (2013). A modern history of fiscal prudence and profligacy. IMF Working Papers 13/5, International Monetary Fund.

McEwan, A. (2001). Neo-liberalism or democracy? Economic strategy, markets and alternatives for the 21st century. London: Zed Books.

Mishra, B. R., \& Jena, P. K. (2019). Bilateral FDI flows in four major Asian economies: A gravity model analysis. Journal of Economic Studies, 46(1), 71-89. Available at: https://doi.org/10.1108/jes-07-2017-0169.

Moran, T. H. (1999). Foreign direct investment and development: A reassessment of the evidence and policy implications. Paper presented at the OECD Conference on the Role of International Investment in Development, Corporate Responsibilities and the OECD Guidelines for Multinational Enterprises Paris, 20-21 September 1999.

Nasiru, I., \& Usman, H. M. (2013). The relationship between domestic savings and investment: The Feldstein-Horioka test using Nigerian data. CBN Journal of Applied Statistics, 4.(1), 75-88.

Nonnenberg, M., \& Mendonca, M. (2004). The determinants of direct foreign investment in developing countries, IPEA.

Okpara, G. (2012). An error correction model analysis of the determinant of foreign direct investment: Evidence from Nigeria. MPRA Paper No. 36676.

Pesaran, M., Shin, Y., \& Smith, R. (1996). Testing for the existence of a long-run relationship. DAE Working Paper No. 9622.

Pesaran, M., \& Shin, Y. (1999). An autoregressive distributed-lag modeling approach to co- integration analysis. Econometric Society Monographs, 31, 313-371.

Pesaran, M. H., Shin, Y., \& Smith, R. J. (2001). Bounds testing approaches to the analysis of level relationships. Journal of Applied Econometrics, 16(3), 289-326. Available at: https://doi.org/10.1002/jae.616.

PWC. (2019). Strength from abroad the economic power of Nigeria's Diaspora, 2019 report. Retrieved from: https://www.pwc.com/ng/en/pdf/the-economic-power-of-nigerias-diaspora.pdf.

Rădulescu, M., \& Druica, E. (2014). The impact of fiscal policy on foreign direct investments. Empiric evidence from Romania. Economic research-Ekonomska istraživanja, 27(1), 86-106. Available at: https://doi.org/10.1080/1331677x.2014.947133.

Salako, H., \& Adebusuyi, B. (2001). Determinants of foreign direct investment (FDI) in Nigeria: An empirical investigation. Economic and Financial Review, 39(1), 20-39.

Shah, M. H. (2016). The effect of macroeconomic stability on inward FDI in African developing countries. International Journal of Business Studies Review (IJBSR) 1(1), 1-12.

Shuaibu, M. (2016). Quantifying the macroeconomic impact of trade liberalisation in Nigeria. CBN Economic and Financial Review, 54(4), 28-48.

Suchismita, B., \& Sudipta, J. (2012). Crisis Exacerbated Fiscal Deficits and Possible Impact on FDI Flows: An Empirical Analysis of Emerging Europe and India. Applied Econometrics and International Development, 12(1), 35-50. 
Taguchi, H., \& Pham, H. K. (2019). Economic effects of inward foreign direct investment in vietnamese provinces. MPRA Paper No. 92032.

Takyi, P. O., \& Obeng, C. K. (2013). Determinants of financial development in Ghana. International Journal of Development and Sustainability, 2(4), 2324-2336.

The World Bank. (1993). The East Asian miracle: Economic growth and public policy. Oxford: Oxford University Press.

Thirlwall, A. P. (1994). Growth and development (5th ed.). London: Macmillan.

Wint, A. G., \& Williams, D. A. (2002). Attracting FDI to developing countries: A changing role for government? The International Journal of Public Sector Management, 15(4/5), 361-374. Available at: https://doi.org/10.1108/09513550210435719.

Yimer, A. (2017). Macroeconomic, political, and institutional determinants of FDI inflows to ethiopia: An ARDL approach. In Studies on Economic Development and Growth in Selected African Countries (pp. 123-151). Singapore: Springer.

\section{Appendix}

1- Log linear regression:

Dependent Variable: LOG(FDI)

Method: Least Squares

Date: 08/26/20 Time: 14:20

Sample (adjusted): 19852017

Included observations: 33 after adjustments

\begin{tabular}{l|l|l|l|l}
\hline Variable & Coefficient & Std. Error & t-Statistic & Prob. \\
\hline C & 13.61044 & 14.24776 & 0.955269 & 0.3486 \\
\hline LOG(HC) & 0.573200 & 0.502060 & 1.141695 & 0.2644 \\
\hline LOG(FCF) & -0.858952 & 0.525288 & -1.635201 & 0.1145 \\
\hline LOG(DCP) & 0.720905 & 0.498392 & 1.446463 & 0.1605 \\
\hline LOG(DS) & 0.163162 & 0.732060 & 0.222880 & 0.8254 \\
\hline LOG(ED) & -0.742566 & 0.378134 & -1.963767 & 0.0608 \\
\hline LOG(FD) & -2.776463 & 1.092268 & -2.541925 & 0.0176 \\
\hline LOG(FR) & 0.417370 & 0.128909 & 3.237719 & 0.0034 \\
\hline R-squared & 0.832755 & Mean dependent var & 7.681132 \\
\hline Adjusted R-squared & 0.785926 & \multicolumn{5}{|l}{ S.D. dependent var } & 0.948430 \\
\hline S.E. of regression & 0.438820 & \multicolumn{4}{|l}{ Akaike info criterion } & 1.397764 \\
\hline Sum squared resid & 4.814084 & \multicolumn{5}{|l}{ Schwarz criterion } & 1.760554 \\
\hline Log likelihood & -15.06310 & Hannan-Quinn criter. & 1.519832 \\
\hline F-statistic & 17.78305 & \multicolumn{5}{l}{ Durbin-Watson stat } & 1.409238 \\
\hline Prob(F-statistic) & 0.000000 & \multicolumn{4}{l}{} \\
\hline
\end{tabular}

2- ARDL Cointegration analysis

Dependent Variable: LOG(FDI)

Method: ARDL

Date: 09/06/20 Time: 14:27

Sample (adjusted): 19872017

Included observations: 31 after adjustments

Maximum dependent lags: 3 (Automatic selection)

Model selection method: Akaike info criterion (AIC)

Dynamic regressors (2 lags, automatic): LOG(HC) LOG(FCF) LOG(DCP)

LOG(DS) LOG(ED) LOG(FD) LOG(FR)

Fixed regressors: $\mathrm{C}$

Number of models evalulated: 6561

Selected Model: ARDL(2, 1, 1, 2, 0, 2, 2, 2)

Note: final equation sample is larger than selection sample 


\begin{tabular}{l|l|l|l|l}
\hline Variable & Coefficient & Std. Error & t-Statistic & Prob.* \\
\hline LOG(FDI(-1)) & -0.336838 & 0.127763 & -2.636429 & 0.0231 \\
\hline LOG(FDI(-2)) & 0.275158 & 0.108183 & 2.543443 & 0.0273 \\
\hline LOG(HC) & -0.837896 & 0.364651 & -2.297801 & 0.0422 \\
\hline LOG(HC(-1)) & 0.690822 & 0.224368 & 3.078969 & 0.0105 \\
\hline LOG(FCF) & 2.540852 & 0.533542 & 4.762237 & 0.0006 \\
\hline LOG(FCF(-1)) & -1.276505 & 0.309481 & -4.124658 & 0.0017 \\
\hline LOG(DCP) & 2.242097 & 0.372339 & 6.021649 & 0.0001 \\
\hline LOG(DCP(-1)) & 1.508331 & 0.417665 & 3.611343 & 0.0041 \\
\hline LOG(DCP(-2)) & 1.230621 & 0.375843 & 3.274294 & 0.0074 \\
\hline LOG(DS) & 0.251571 & 0.414621 & 0.606750 & 0.5563 \\
\hline LOG(ED) & -0.658907 & 0.271088 & -2.430600 & 0.0334 \\
\hline LOG(ED(-1)) & -0.686114 & 0.347079 & -1.976824 & 0.0737 \\
\hline LOG(ED(-2)) & 1.153437 & 0.317842 & 3.628960 & 0.0040 \\
\hline LOG(FD) & -0.591816 & 0.841778 & -0.703055 & 0.4966 \\
\hline LOG(FD(-1)) & -0.814464 & 0.791107 & -1.029525 & 0.3253 \\
\hline LOG(FD(-2)) & -4.221006 & 0.761950 & -5.539738 & 0.0002 \\
\hline LOG(FR) & 0.013316 & 0.120282 & 0.110705 & 0.9138 \\
\hline LOG(FR(-1)) & 0.152589 & 0.181080 & 0.842663 & 0.4174 \\
\hline LOG(FR(-2)) & -0.686394 & 0.162027 & -4.236282 & 0.0014 \\
\hline C & -28.17566 & 10.38725 & -2.712524 & 0.0202 \\
\hline R-squared & 0.986423 & \multicolumn{2}{|l}{ Mean dependent var } & 7.807361 \\
\hline Adjusted R-squared & 0.962972 & S.D. dependent var & 0.820771 \\
\hline S.E. of regression & 0.157937 & \multicolumn{2}{|l}{ Akaike info criterion } & -0.599006 \\
\hline Sum squared resid & 0.274386 & Schwarz criterion & 0.326147 \\
\hline Log likelihood & 29.28459 & \multicolumn{2}{|l}{ Hannan-Quinn criter. } & -0.297429 \\
\hline F-statistic & 42.06347 & Durbin-Watson stat & 3.106349 \\
\hline Prob(F-statistic) & 0.000000 & & & \\
\hline & & &
\end{tabular}

*Note: p-values and any subsequent tests do not account for model selection. 
ARDL Bounds Test

Date: 09/06/20 Time: 14:31

Sample: 19872017

Included observations: 31

Null Hypothesis: No long-run relationships exist

\begin{tabular}{c|c|c}
\hline Test Statistic & Value & $\mathrm{k}$ \\
\hline F-statistic & 12.86530 & 7 \\
\hline Critical Value Bounds \\
\hline Significance & Io Bound & I1 Bound \\
\hline $10 \%$ & 1.92 & 2.89 \\
\hline $5 \%$ & 2.17 & 3.21 \\
\hline $2.5 \%$ & 2.43 & 3.51 \\
\hline $1 \%$ & 2.73 & 3.9 \\
\hline
\end{tabular}

Long Run Coefficients

\begin{tabular}{l|l|l|l|l}
\hline Variable & Coefficient & Std. Error & t-Statistic & Prob. \\
\hline LOG(HC) & -0.138529 & 0.348766 & -0.397198 & 0.6988 \\
\hline LOG(FCF) & 1.190894 & 0.375086 & 3.174985 & 0.0088 \\
\hline LOG(DCP) & 4.691670 & 0.590634 & 7.943452 & 0.0000 \\
\hline LOG(DS) & 0.236956 & 0.399324 & 0.593393 & 0.5649 \\
\hline LOG(ED) & -0.180454 & 0.306244 & -0.589248 & 0.5676 \\
\hline LOG(FD) & -5.300363 & 0.786937 & -6.735436 & 0.0000 \\
\hline C & -0.490250 & 0.134015 & -3.658181 & 0.0038 \\
\hline
\end{tabular}

